ISSN 2338-4778 (Print)

ISSN 2548-4192 (Online)

Volume 8, Number 1, June 2020

pp. $321-331$

\title{
An Analysis of Flouting Maxim in Ruby Spark Movie
}

\author{
Lasiana*1, Zia Hisni Mubarak ${ }^{2}$ \\ lasiana07081995@gmail.com \\ * English Department, Putera Batam University
}

Received: 19 May 2020 Accepted: 17 June 2020

DOI: 10.24256/ideas.v8i1.1348

\begin{abstract}
This article describes the study of pragmatics in a specific domain of flouting maxim found in Ruby Spark movie. The aim of this study is to find out the type of flouting maxim found in the utterances between the characters in the movie. The theory used in this research was Grice (1972). In this research, the researcher applies the qualitative descriptive method. The method of collecting data is observation. The steps are watching the Ruby spark movie during their conversation. The result is there are four types of flouting maxims found in the movie. Eight data for flouting quantity, one for maxim of quality, and four for maxim of relevant and three for maxim of manner. And the most dominant flouting appear is maxim of quantity because they wanted to give additional information.
\end{abstract}

Keywords: flouting maxim, maxim, pragmatics

\section{Introduction}

Humans are social beings and usually talk with others. With doing conversation, it gives information and also getting information by speaking contextually. Context is one of the key to get the cooperative principle in doing conversation. According to (Mugheri, Ayaz, Qureshi, \& Mugheri, 2018) The context has to be conducted by a speaker and a listener to avoid misunderstanding of what they are communicating. Interaction can be built when both speaker and listener have a cooperative principle in doing conversation. Cooperative means that the speaker knows in each utterance that speaker said. Cooperative principle also provides how to have a cooperative conversation by designating conversational maxim. It is also sometimes named Grice's or Gricean maxims. (Fukumura \& van Gompel, 2017) Grice's maxims make the fundamental assumption that language comprehension is led by a default expectation that an utterance should be optimally informative. So it can be said maxims related to the success of a 
conversation depends on the various speaker' approach to the interaction.

In this situation, there are still people who disobeying the rule with do not contribute to the conversation and they do not give the appropriate answer. Whereas the people should participate in a conversation such as telling the truth, being relevant, and trying to be as clear as they can in order to make the conversation run smoothly. When people obey the maxim, this can be called as observed maxim. Beside of observed maxim, there is also non- observed maxim. Non observed maxim is if someone do not obey the maxim and make the conversation do not run well. One of non- observed maxim is flouting maxim. According to Cutting (2002) flouting happens when a speaker fails to observe a maxim in which they have intention. When flouting is working, it may be to effectively communicate a message. It can be concluded that in doing conversation, knowing the context and how to respond to the utterances are needed. People should know what kind of flouting maxim that they flouted. Flouting maxim that people breaking up have relation to the types of flouting maxim itself. Grice (1972) stated that the flouting maxims consist of four maxims. They are flouting maxim of quantity, quality, relation, and manner. Each of them covers one aspect of linguistics and describes the different types with showing disrespect to the maxim.

Disrespecting this maxim, these four flouting maxims are also important to know, they are also indicative of voicing the speech of people impolitely and speaking rude words. For example, if people give too much information and additional information that is not needed or overwhelm information, it can harm the sense of the individual that is not the right form of what they are talking about because sometimes the speaker wants the right answer in their conversation. "People can refuse to follow a maxim because they are unable to speak clearly, for example, or because they intentionally choose to lie and cover up something" (Thomas, 1995 p. 64)

They are some researchers that have the similar and continuing analyze about flouting maxim. The first study about flouting maxim was done by Affifatusholilah (2016). The title is about Flouting Maxim by Sherlock Holmes and Dr. Watson in TV Series of Sherlock season 1 . The aims of this paper are to describe types of maxims that are flouted and how the maxims are flouted by Sherlock Holmes and Dr. Watson season 1. They analyzed the utterances which are constructed in crime drama television series in Sherlock TV series season 1. To support their research, they use the Grice's theory. The result of this research, they found kinds of maxims are flouted in the Sherlock TV series season 1 and also concluded that the speakers in the movie flouted maxim of relation by saying something irrelevant with the question to hide the truth, said something too informative and ambiguity.

Importantly, the study should investigate in depth the forms of flouting maxims. Grice said flouting quantity rule means not saying enough, say too much. The flouting maxim of quality implies that they are not telling the truth and that is not true information. The flouting of relevant implies that people don't say the relevant response based on what's required. And the last is the flouting maxim of 
manner means people do not give the brief, clear, and ambiguous. Through this theory the researcher gives example.

Grace: Do you have time for watching movie tomorrow?

Boy: I have classes all day and I also join the extra-curricular.

In this example, Boy flouted the maxim of quantity because giving too much information, rather than providing a yes or no answer. The reason of flouting this maxim is because Boy actually does not want to watch movie but he avoids saying the truth and refusing directly.

Some writings, such as novel, short story, and also movie script can be found based on the examples above flouting maxim. The researcher used movie as his source, Ruby spark is one of the movie that has a interesting plot and topic and it has been a best seller in 2012. Based on the case and the phenomena in the movie, so the researcher was interested in taking this subject to learn more and telling people about the important principles of cooperation.

Cooperative Principle is the basic principle in pragmatics in which people are strived to make their conversation as cooperative as possible, in line with the purpose of the conversation. Yule (2010) stated that his principle results from the common assumption about communication as a cooperative effort. In this principle, there are four sub-principles called maxims which provide more detailed principles of conversational cooperation. Maxim Flouting, Maxim flouting is intentionally breaking the maxims in order to convey hidden meanings and lead the listener to find out the implied meaning from the maxim flouting. This form of non-observance of maxims is explained further in the next review. Grice (1972) stated that the types of maxim flouting are divided into the same number of the maxims of Cooperative Principle. Therefore, there are four types of maxim flouting; they are quantity maxim flouting, quality maxim flouting, relevance maxim flouting, and manner maxim flouting.

Quantity of Maxim Flouting, Quantity maximum flouting means that a conversation speakers fail to meet the Cooperative Principle maximum quantity. This involves whether the speakers are not as informative as possible, as or more informative than required. Quality of Maxim Flouting, when the speaker disregards this concept, it does not represent what she / he believes to achieve the highest quality; a theory that allows the speaker to make a real contribution, that does not say what is supposed to be false and does not say what the speaker lacks sufficient evidence for. Relevance Maxim Flouting, relevance maxim flouting means that the speakers of a conversation fail to be relevant in communicating. Speakers are usually being irrelevant in flouting maxim of relevance. However, being irrelevant does not purely mean that the speakers do not want to be relevant. Sometimes, speakers are being irrelevant because they want to hide something or to say something to others indirectly. For example

Bert: Do vegetarians eat hamburgers? Ernie: Do chickens have lips?

From the example, Ernie is being irrelevant in this conversation. Ernie should give a' yes' or' no' response, as expected. Since the answer was obvious, however, 
Ernie flouts maximum relevance to emphasize her' no' response. Here, by being insignificant, Ernie flouts maxim of relevance and is effective in conveying its unstated significance.

Manner Maxim Flouting, To be clear in saying things is what all speakers try to do. However, in some occasion, ambiguity indeed happens whether the speaker intends to make it or not. Then, maxim of manner is not fulfilled as the result.

There are some researchers that had conducted this research by some related to the topic. The first one is from Zebua (2017) they analyze the violation and flouting of quantity maxims, relevance, and manner by male and female participants in the Ellen Degeneres Talk show. According to them, the flouting of maxim happens when individual intentionally do not apply the maxims in order to persuade their listeners to derive the hidden meaning behind what they said. The data is taken from six episodes in the newest edition in 2016 from Ellen talk show. The result reveals that the male mostly uses the flouting maxim. This research is different because they also examined the violation in the talk show. The second was done by Yuliasri (2014) who has a title The Shift of Grice's Maxim Flouting in Indonesian Translation of the Donald Duck Comics. She examined that the flouting maxim could result in humor. The data was taken from the Donald Duck Comics. This study reveal that $34.79 \%$ of translated humorous utterances in the Donald Duck Comics. The most dominant flouting maxim that appears is the maxim of manner

\section{Method}

In collecting data, the researcher used observation method. Based on Sudaryanto (1993) He states that observation method is a technique to get information about human behavior by watched and recorded without any direct contact. Because of that the researcher used observation method because watching the movie.

In this research, the researcher used non participatory technique to collect the data because there is no one involve. There are some procedures which the researcher will do in collecting the data.

1. The first, the researcher downloaded the movie

2. Second, open the Ruby Spark movie.

3. Third, watching the movie.

4. Classifying the data in the movie based on Grice's theory.

In analyzing the data, the researcher applied theory from Grice's theory. The theory is applied by using method of Sudaryanto (1993) by using Pragmatics Identity Method. Pragmatics Identity method is method that based on contextual situation.

1. Classifying the data into types flouting maxim based on Grice's theory from the Ruby Spark movie". 2. Analyzing the types of flouting maxim based on Grice's theory. 3. The data were described to answer those categories based on research 
question.

After doing analysis, the next step is presenting the result analysis. The researcher used informal method which informal method refers to the process of presenting the outcome analysis with words. The result was presented by using words and sentences and to make the readers easily understand.

\section{Results and Discussion}

After analyzing the utterances in Ruby Spark movie by Zoe Kazan, the study found that there are four types of flouting maxim that used among the characters in the movie. They are flouting maxim of quantity, flouting maxim of quality, flouting maxim of relevance, and flouting maxim of manner. There is also the variety of reasons found in the utterances.

\section{Flouting Maxim of Quantity}

\section{Data 1:}

Dr. Rosenthal: are you sure?

Calvin: yes I'm sure!!!! She's a mother product of my imagination

Dr. Rosental is private doctor for Calvin and his family. Because Calvin has problem with his imagination. This conversation is the data of flouting maxim quantity. It can be seen when Dr. Rosental asked "are you sure?" but he answered with the long answer. He flouted this maxim of quantity because he wanted to explain more about her feeling that it might not be possible.

\section{Data 2:}

Calvin: Wait wait wait. You can see her?

Ruby: She can see me, I can see her. Did you

This conversation is the data of flouting maxim of quantity. Ruby was flouting this maxim because she was providing more information that is needed. It could be seen when Ruby answered Calvin's question with too little details. She offers "she can see me, I can see her, did you think?" which actually could be answered a simple and follow the rule like "Yes, I can."

\section{Data 3:}

Mort: So did you go to art school?

Ruby: Um, not formally, no. I just kind of picked things up along the way.

This conversation happens when Ruby came to Calvin's parent house. This conversation is the data from flouting of maxim quantity. It can be said that she gave the long information and she made her contribution more than is required with saying "Um, not formally, no. I just kind of picked things up along the way."

\section{Data 4:}


An Analysis of Flouting Maxim In Ruby Spark Movie

Mort: Don't you like it?

Gertrude: Of course he does. It's a great chair!

This situation happened when Mort wanted to give the chair for Calvin and Ruby. This conversation is the data of flouting maxim quantity. It can be seen from the Gertrude's utterance that he was overload answering Mort's question. He answered with "Of course he does. It's a great chair!." The reason why Gertrude flouted this maxim because he wanted to explain more about the reason, so the hearer will understand that the chair was the great chair.

\section{Data 5:}

Ruby: he was golfer? *

Gertrude: Jack tried many, many things. It was hard for him...to see things come so easily for Calvin. He couldn't understand. A great gift can be a burden in its own right. It can be lonely.

This situation happened when Ruby was asking about her husband and thought that he was a golfer. Gertrude answered it with the long answer and explanation. From that situation, Gertrude was flouting maxim of quantity. It can be seen when Gertrude was answering with the long answer "Jack tried many, many things. It was hard for him...to see things come so easily for Calvin. He couldn't understand. A great gift can be a burden in its own right. It can be lonely." which is actually unnecessary. Gertrude actually just had to answer yes or no to fulfill the maxim of quantity.

\section{Data 6:}

Cyrus: What are you doing? You have to talk to Adam and Mandi.

Calvin: Who?

Cyrus: Adam and Mandi. The producers who want to take over your option? Check your messages.

This is one of flouting maxim of quantity. Cyrus replied it and explained who Calvin must to see. Maxim of quantity is fulfilled when someone obeys with giving the information that is only needed. But if someone does not obey it, it means that they flout maxim of quantity. In this case, Cyrus flouted maxim of quantity. It is proven when Calvin asked "who?" and Cyrus answered with giving additional answer rather that "No." She gave the long answer "Adam and Mandi. The producers who want to take over your option? Check your messages."

\section{Data 7:}

Girl: Is he Scottish?

Calvin: I named him for F. Scott Fitzgerald.

This is one of flouting maxim of quantity. Calvin replied it and explained who 
Scottish is. Maxim of quantity is fulfilled when someone obeys with giving the information that is only needed. But if someone does not obey it, it means that they flout maxim of quantity. In this case, Calvin flouted maxim of quantity. It is proven when Girl asked "is it Scottish?" and Calvin answered with giving additional answer rather that "No."

\section{Data 8:}

Ruby: Would you have been mad if I was wearing my bikini?

Calvin: You weren't wearing your bikini. Do you know how it looked? My agent was there. My ex was there!

This is one of flouting maxim of quantity. Calvin replied it and explained why Ruby cannot use bikini. Maxim of quantity is fulfilled when someone obeys with giving the information that is only needed. But if someone does not obey it, it means that they flout maxim of quantity. In this case, Calvin flouted maxim of quantity. It is proven when Ruby asked "Would you have been mad if I was wearing my bikini?" and Calvin answered with giving additional answer rather that "No." He gave the long answer "You weren't wearing your bikini. Do you know how it looked? My agent was there. My ex was there!"

\section{Flouting Maxim of Quality}

\section{Data 1:}

Harry: Golf tomorrow?

Calvin: I'm seeing Cyrus. (He softens.) Maybe Friday.

The conversation happened when Harry asked about Calvin to have golf. Calvin answered it with doubt. This data can be categorized as flouting maxim of quality. When the speaker disregards this principle, it did not reflect what they believed to achieve the highest quality; a maxim that allows the speaker to make a contribution that is real, that doesn't say what is assumed to be false and does not say what the speaker lacks sufficient proof for. So Calvin did not convince that he could play golf tomorrow.

\section{Data 2:}

Ruby: I'm sorry. Everything's been so up and down recently. It's like my internal compass is just...gone. Maybe I should talk to someone. You used to see someone, right?

Calvin: Dr. Rosenthal.

Ruby: Maybe you should go back.

The conversation happened when Calvin might think he was crazy because his dream girl became a real one. He asked maybe he could meet doctor. Calvin answered it with doubt. This data can be categorized as flouting maxim of quality. 
When the speaker disregards this principle, it did not reflect what they believed to achieve the highest quality; a maxim that allows the speaker to make a contribution that is real, that doesn't say what is assumed to be false and does not say what the speaker lacks sufficient proof for. So Calvin did not convince that he would come or not to the doctor

Flouting Maxim of Relevant

\section{Data 1:}

Calvin: Who's that?

Harry: You tell me...

This conversation happened when Calvin saw something strange in his house and he asked who that was. This conversation is the data of flouting maxim relevant. If the speakers of a conversation failed to be relevant in communicating, they will flout maxim of relevant. It can be seen from Harry's utterance that he gave unnecessary additional information; Harry flouted the maxims of relevance by giving unnecessary additional information to the topic being talked about.

\section{Data 2:}

Ruby: Were you disappointed? When you got to know me? *

Calvin: How can you ask that?

From the utterance above, it happened when Calvin and Ruby were talking about their first meeting. When Ruby asked Calvin, Calvin did not answer the question directly to the point. This could happen if people did not want to say directly, they flouted maxim of relevant by saying "how can you ask that?" Calvin decided not to answer the conversation topic. That is why he flouted maxim of relevant.

\section{Data 3:}

Calvin: Hi, where are you?

Ruby: Yeah, um, a bunch of people from class decided to go out.

From the utterance above, it happened when Calvin and Ruby were not together because of any problem. When Calvin asked Ruby, Ruby did not answer the question directly to the point. This could happened if people did not want to say directly, they flouted maxim of relevant by saying "Yeah, um, a bunch of people from class decided to go out" Ruby decided not to answer the conversation topic. That is why she flouted maxim of relevant.

\section{Data 4:}

Calvin: Can you not feed Scotty off the table?

It'll upset his stomach. * 
Mort: Don't worry! Dogs love human food.

This conversation happened when Calvin told Mort not to feed his dog. This conversation is the data of flouting maxim relevant. If speakers of a conversation failed to be relevant in communicating. It can be seen from Mort's utterance that he gave unnecessary additional information; Mort flouted the maxims of relevance by giving unnecessary additional information to the topic being talked about.

\section{Flouting Maxim of Manner}

\section{Data 1:}

Ruby: Calvin! I forgot to tell you. Your mom's going to teach me how to bake a pie. She says we can pick the berries straight from the garden.

(Getting in bed) Isn't that cool? Calvin?

Calvin: She didn't used to be like this.

This situation happened when Ruby asked to Calvin that his mom taught her to cook. When Ruby asked "isn't that cool?" Calvin replied "she didn't used to be like this." Here, Ruby has flouted maxim of manner with saying "She didn't used to be like this." This sentence can be said that is ambiguous. The reason why Calvin flouted this maxim is to get attention, sometimes people use identical word in one situation to get attention from others.

\section{Data 2:}

Harry: You're so beautiful. Isn't she the most beautiful girl?

Susie: Okay, time for bed. Come on, crazy.

This conversation happened when Harry asked Susie about his new girlfriend whether she was beautiful or not. But Susie did not answer directly towards to the question. This conversation is one of flouting maxim of manner, which did not give the relevance answer based on the question that had been talked about. She preferred to answer "Okay, time for bed. Come on, crazy." The reason is she did not want to talk about this matter again.

\section{Data 3:}

Mandy: Who would you want to play Charlie?

Adam: That's the question, right?

This situation happened when Mandy asked to Charlie in reunited school. When Mandy asked "Who would you want to play Charlie?" Adam replied "That's the question, right?" Here, Adam has flouted maxim of manner with saying "That's the question, right?" This sentence can be said that is ambiguous. The reason why Adam flouted this maxim is to get attention sometimes people use identical word 
An Analysis of Flouting Maxim In Ruby Spark Movie

in one situation to get attention from others.

After analyzing the data, the research found some findings. There are 4 types of flouting maxim found related to the flouting that they had flouted in Ruby Spark movie by Zoe Kazan during their conversation the movie itself.

The researcher also found the data take from the movie. From the result of the data in the table above, total of the utterances which contain flouting maxims are 11 utterances. The data can be classified as 4 types, they are flouting maxim of quantity 8 data, and flouting maxim of quality only 2 data, flouting maxim of relevant 4 data, and the last is flouting maxim of manner 3 data.

The most dominant appear is flouting maxim of quantity which has 8 data. The reason is because all the character wanted to show their explanation regarding to the plot. To make the answer more detail and easy to be understood.

\section{Conclusion}

From all the research analysis and finding above, it is important to know whether they flouted the maxim and why they did that. This article can classify the type of flouting maxim in Ruby Spark movie. The finding reveals that the characters like to obey the cooperative principle unconsciously but others still understood what they talked about. As a result of this research, it contains flouting maxim of quantity, quality, relevant, and manner.

After all the data research found and the conclusion was made, the research gives suggestion for the reader who reads this research. For the other researchers who is going to analyze this research, they should do this research with the direct source because if they analyze in novel, movie, and script. It would be easier. For the reader who is student or ordinary people, they must consider their talk between each other because misunderstanding always happens, but the important is being polite and not saying words that could insult people is the point.

\section{References}

Burhan, R., Mulyawan, I. W., \& Sedeng, I. N. (2018). Flouting Maxim in BBC Series "Sherlock: A Study In Pink." Humanis, 22(1973),764. https://doi.org/10.24843/jh.2018.v22.i03.p29

Cutting,J.(2002). Pragmatics and discourse: A resource book for students. London: Routledge.

Grice, H. P. (1972). Intention and uncertainty. New York: Oxford University Press. Lina, A, A. H. S. (2016). Flouting maxim by Sherlock holmes and Dr. Watson in TV series of Sherlock season 1. Journal of English Language and Education, 2(2), 12. https://doi.org/2541-6421 
Masruddin, M. (2018). Lessons in Old Man and The Sea. IDEAS: Journal on English Language Teaching and Learning, Linguistics and Literature, 1(1). doi:https://doi.org/10.24256/ideas.v1i1.126.

Mugheri, N. A., Ayaz, P., Qureshi, A., \& Mugheri, R. A. (2018). The Importance of Pragmatics in English Language Teaching. 18(49042), 112-125.

Sudaryanto. (1993). Method dan teknik analysis bahasa. Yogyakarta: Duta Wacana University Press.

Thomas, J. (1995). Learning about language meaning in interaction. United Kingdom: Cambridge University Press.

Tsamratul'aeni, T. (2019). Politeness Strategy Used by Lecturer in Teaching Process. IDEAS: Journal on English Language Teaching and Learning, Linguistics and Literature, 7(2). doi:https://doi.org/10.24256/ideas.v7i2.1036

Yule, G. (2010). The study of language (4th ed.). New York: Cambridge University Press.

Yuliasri, I. (2014). The shift of Grice's maxim flouting in Indonesian translation of the Donald Duck comics. Arab World English Journal, (3), 225-238. Retrieved from

http://proxy.libraries.smu.edu/login?url=http://search.ebscohost.com/login.a spx?direct=true $\& \mathrm{db}=$ eue $\& A N=97342850 \&$ site $=$ ehost-live $\&$ scope $=$ site

Zebua, E. (2017). The violation and flouting of cooperative principles in the Ellen Degeneres Talk Show. Language Circle - Journal of Language and Literature, 12(1), 103-113. https://doi.org/10.15294/lc.v12i1.11474 